\title{
AGE, GROWTH RATE, AND CONDITION OF VENDACE, COREGONUS ALBULA (L.), FROM SOME POMERANIAN LAKES (NW POLAND)
}

\author{
Przemysław CZERNIEJEWSKI, Mariusz RACZYŃSKI, Wawrzyniec WAWRZYNIAK
}

\author{
Division of Fisheries Management of Inland Waters, Agricultural University of Szczecin, Poland
}

Czerniejewski P., Raczyński M., Wawrzyniak W. 2006. Age, growth rate, and condition of vendace, Coregonus albula (L.), from some Pomeranian Lakes (NW Poland). Acta Ichthyol. Piscat. 36 (1): $65-72$.

Background. Vendace, Coregonus albula (L.), is one of the most valuable components of Polish lake ichthyofauna. The vendace from different lakes differ in their principal vital characteristics (such as growth rate etc.) and it is therefore crucial to determine those characteristics from different throphic types of lakes in order to implement proper measures of fisheries management for those coregonids. The aim of the present paper was therefore to learn principal biological features of vendace populations representing three different Pomeranian lakes.

Materials and Methods. Comparative biological studies were carried out on 136 vendace from Pełcz Wielki Lake, 304 from Bytyń Wielki Lake, and 62 from Wełtyń Lake (Pomerania Lakeland) collected within 2002-2003. The age and growth rate of the fish were determined from scales. Fulton's condition factor and the total length-weight relation were used to determine fish condition.

Results. Gillnet selectivity influenced fish age structure and size. For example, among 502 vendace obtained, in total, from the three lakes, $75.7 \%$ (380 specimens) were $2+$. The results of back-calculations and the parameters of von Bertalanffy's growth equation revealed distinct disproportions in the total length in individual age groups (Pełcz Wielki Lake: $L_{\mathrm{t}}=213.22\left[1-e^{-0.49576(1+1.055013)}\right]$; Bytyń Wielki Lake: $L_{\mathrm{t}}=219.17\left[1-e^{-0.733553(1+0.040147)}\right]$; Wełtyń Lake: $\left.L_{\mathrm{t}}=255.08\left[1-e^{-0.571108(1+0.023036)}\right]\right)$ Slower length- and weight growth rates were observed in the fish from Pełcz Wielki Lake.

Conclusions. The growth rates, determined using back-calculations, were different for the vendace populations representing lakes Pełcz Wielki, Bytyń Wielki, and Wełtyń in the sequential years of fish lives. The fish from Wełtyń Lake were characterized by average growth, whilst the fish from the remaining reservoirs were characterized by slow or very slow growth. The lower condition values and growth rates from Pełcz Wielki Lake were probably the result of poor environmental conditions in this body of water.

Keywords: fish, vendace, Coregonus albula, growth rate, condition, age

\section{INTRODUCTION}

The vendace, Coregonus albula (L.), is one of the most valuable fish species caught in Polish lakes. The factors contributing to its high value are: high quality meat, fast growth rate, shoaling behaviour, and high market value. These qualities explain why, despite the high environmental requirements of this species, its catch had been increasing systematically in Poland, in the 1980 s, reaching almost $600 \mathrm{t}$ per year. However, due to the transformation of the fishing industry, the vendace fishery decreased twofold in the 1990s (Leopold and Wołos 1999). The disappearance of Coregonus sp. in lakes has also been related to adverse changes resulting from. Vendace are found in 44 out of 1575 lakes of Polish western Pomerania (Filipiak and Raczyński 2000), although only 23 of them are explored by professional fishermen (Czerniejewski and Filipiak 2001). Unfortunately, due to a lack of knowledge on the biological features of vendace populations inhabiting these waters it is impossible, in many cases, to implement a reasonable fisheries management. We decided to focus our attention on three, hitherto not studied, vendace populations inhabiting lakes Pełcz Wielki, Bytyń Wielki and Weltyń (Table 1) and to determine the biological features of those fish, in particular their age structure, growth rate, and condition.

\section{MATERIALS AND METHODS}

Vendace, Coregonus albula (L.), collected for the presently reported study were caught at night with a 24-mmmesh-size gillnets in lakes: Pełcz Wielki (136 specimens; 
Table 1

Morphometric features and water quality parameters of lakes: Pełcz Wielki, Bytyń Wielki, and Wełtyń

\begin{tabular}{|c|c|c|c|}
\hline Morphometric and quality data & $\begin{array}{c}\text { Pełcz Wielki } \\
\text { Lake }\end{array}$ & $\begin{array}{c}\text { Bytyń Wielki } \\
\text { Lake }\end{array}$ & $\begin{array}{l}\text { Wełtyń } \\
\text { Lake }\end{array}$ \\
\hline \multicolumn{4}{|c|}{ Morphometric data (Jańczak 1996) } \\
\hline Latitude $(\Phi)$ & $53^{\circ} 00.0^{\prime}$ & $53^{\circ} 17.4^{\prime}$ & $53^{\circ} 14.6^{\prime}$ \\
\hline Longitude $(\lambda)$ & $15^{\circ} 21.5^{\prime}$ & $16^{\circ} 16.4^{\prime}$ & $14^{\circ} 35.0^{\prime}$ \\
\hline Water surface area [ha] & 279.5 & 877.1 & 310.10 \\
\hline Max. length [m] & 7600 & 10800 & 3700 \\
\hline Max. width [m] & 660 & 2610 & 1680 \\
\hline Length of shore line $[\mathrm{m}]$ & 19762 & 38750 & 13795 \\
\hline Elongation index & 11.50 & 13.3 & 2.20 \\
\hline Max. depth $[\mathrm{m}]$ & 31.0 & 41.0 & 11.6 \\
\hline Mean depth $[\mathrm{m}]$ & 12.2 & 10.4 & 4.5 \\
\hline Lake exposure index $\left[\mathrm{ha} \cdot \mathrm{m}^{-1}\right]$ & 22.9 & 84.3 & 68.9 \\
\hline Shoreline complexity index & 3.33 & 3.69 & 2.18 \\
\hline
\end{tabular}

Lake quality (WIOŚ Szczecin, unpublished)

\begin{tabular}{llcc} 
Point score of lake quality & II & II & II \\
Category of degradation susceptibility & II & I & III \\
\hline
\end{tabular}

10 June 2003), Bytyń Wielki (304 specimens; 19 June-25 October 2002), and Wełtyń (62 specimens; 5 June-21 September 2003). The fish were individually weighed (Axis electronic scales with 0.1 -g accuracy) and measured (total length) (electronic Vernier calliper with $0.1-\mathrm{mm}$ accuracy). The condition of the fish studied was determined using the Fulton's condition factor (Ricker 1975, Bolgier and Connolly 1989, Nash et al. 2006) and through analysis of " $n$ " and " $K$ " parameters of the (total) length and weight $(L-W)$ relation. Fish age and growth rates were estimated from their scales, collected following the method of Bernatowicz (1952). The scales were cleaned of the mucus residues with ammonia solution and mounted on slides. Fish age determination and the measurement of scale radius were performed on the oral parts of the scales using image analysis software ("MultiScan" with 0.001$\mathrm{mm}$ accuracy). Due to the commonly known linear $R-L$ relation of venadce, the back calculations were made using the Rosa-Lee procedure, assuming the length of the scale establishment as $30 \mathrm{~mm}$ (Grudniewski 1970). The empirical data thus obtained were used for the theoretical representation of length growth, described by the von Bertalanffy growth equation (Begenal 1978). The weight growth of fish was estimated by calculating the length of the fish in the following years on their weight according to the equation $W=K \cdot L^{\mathrm{n}}$, where $W$ is total individual weight [g], $L$ is total length (TL) [mm], $K$ and $n$ are parameters of $L-\mathrm{W}$ relation.

\section{RESULTS}

The data presented in Table 2 suggest a lack of significant differences among the three populations in relation to mean length and weight. The homogeneity of values obtained can be explained by the mesh size used $(24 \mathrm{~mm})$ for all gillnet catches. Out of a total of 502 vendace collected, 75.7\% (380) were aged 2+. In lakes Bytyń Wielki and Wełtyń, $2+$ fish constituted more than $80 \%$ of all fish caught $(82.2 \%$ and $80.6 \%$, respectively). In Pełcz Wielki Lake, despite the domination of $2+$ fish $(58.8 \%)$, a rather large proportion of $1+$ fish was noted $(23.5 \%)$, compared to the remaining lakes. Significant disproportions between the number of males and females obtained were probably related to the period of catching (Table 2). Among 136 specimens of vendace from Pełcz Wielki Lake, which were collected in spring, females predominated (66.9\%), whilst fish obtained from autumn catches from Lakes Bytyń Wielki and Wełtyń were characterized by greater numbers of males $(82.2 \%$ and $74.2 \%$, respectively)

Fulton's condition factor of for the three populations is shown in Table 2. The difference in condition between vendace from lakes Pełcz Wielki and Wełtyń (0.75 and 0.76 , respectively) were insignificant. Slightly higher condition factor was determined for vendace from Bytyń Wielki Lake (0.79).

Fig. 1 shows the dependence between the fish length and weight for the three populations. The exponent values ( $n$ ) exceeded 2.5 in all cases, with the highest value obtained for fish from Wełtyń Lake $(n=3.5748)$. Much higher variation was noted for the multiplier $(K)$, which ranged from 0.0000004 to 0.00006 . Note that the $n$ values are in reverse proportion to $K$ values.

Growth rates, determined on the basis of back-calculations, are shown in Table 3. All three populations achie- 
Table 2

The average individual weights, total lengths and condition coefficients of vendace from particular lakes

\begin{tabular}{|c|c|c|c|c|c|c|c|c|}
\hline \multirow{2}{*}{ Lake } & \multirow{2}{*}{ Fish age } & \multirow{2}{*}{$+/ 0^{x}$} & \multicolumn{2}{|c|}{ Total length [mm] } & \multicolumn{2}{|c|}{ Individual weight [g] } & \multicolumn{2}{|c|}{ Fulton's condition factor } \\
\hline & & & Mean & Range & Mean & Range & Mean & Range \\
\hline \multirow{5}{*}{ Pełcz Wielki } & $1+$ & $18 / 14$ & 173.3 & $154.3-199.4$ & 40.2 & $31.0-58.3$ & 0.75 & $0.64-0.90$ \\
\hline & $2+$ & $54 / 26$ & 190.0 & $170.8-212.6$ & 51.0 & $38.3-70.0$ & 0.75 & $0.62-0.86$ \\
\hline & $3+$ & $19 / 4$ & 200.4 & $185.7-216.8$ & 61.4 & $53.1-74.6$ & 0.76 & $0.67-0.89$ \\
\hline & $4+$ & $0 / 1$ & 196.5 & - & 59.6 & - & 0.77 & - \\
\hline & Total & $91 / 45$ & 187.9 & $154.3-216.8$ & 50.3 & $31.0-74.6$ & 0.75 & $0.66-0.90$ \\
\hline \multirow{4}{*}{ Bytyń Wielki } & $1+$ & $6 / 18$ & 199.5 & $182.0-214.0$ & 63.8 & $51.3-81.5$ & 0.80 & $0.69-0.91$ \\
\hline & $2+$ & $37 / 213$ & 201.5 & $182.0-236.0$ & 64.2 & $49.5-119.5$ & 0.78 & $0.65-0.96$ \\
\hline & $3+$ & $11 / 19$ & 215.0 & $191.0-273.0$ & 79.2 & $48.8-150.1$ & 0.80 & $0.68-1.01$ \\
\hline & Total & $54 / 250$ & 202.7 & $182.0-273.0$ & 65.7 & $48.8-150.1$ & 0.79 & $0.65-1.01$ \\
\hline \multirow{4}{*}{ Wełtyń } & $1+$ & $1 / 0$ & 180.4 & - & 37.5 & - & 0.70 & - \\
\hline & $2+$ & $8 / 42$ & 201.4 & $176.6-224.7$ & 65.5 & $34.2-100.8$ & 0.79 & $0.59-1.09$ \\
\hline & $3+$ & $7 / 4$ & 203.8 & $186.9-222.2$ & 68.8 & $46.0-93.5$ & 0.80 & $0.69-1.00$ \\
\hline & Total & $16 / 46$ & 199.6 & $176.6-224.7$ & 61.3 & $34.2-100.8$ & 0.76 & $0.59-1.09$ \\
\hline
\end{tabular}




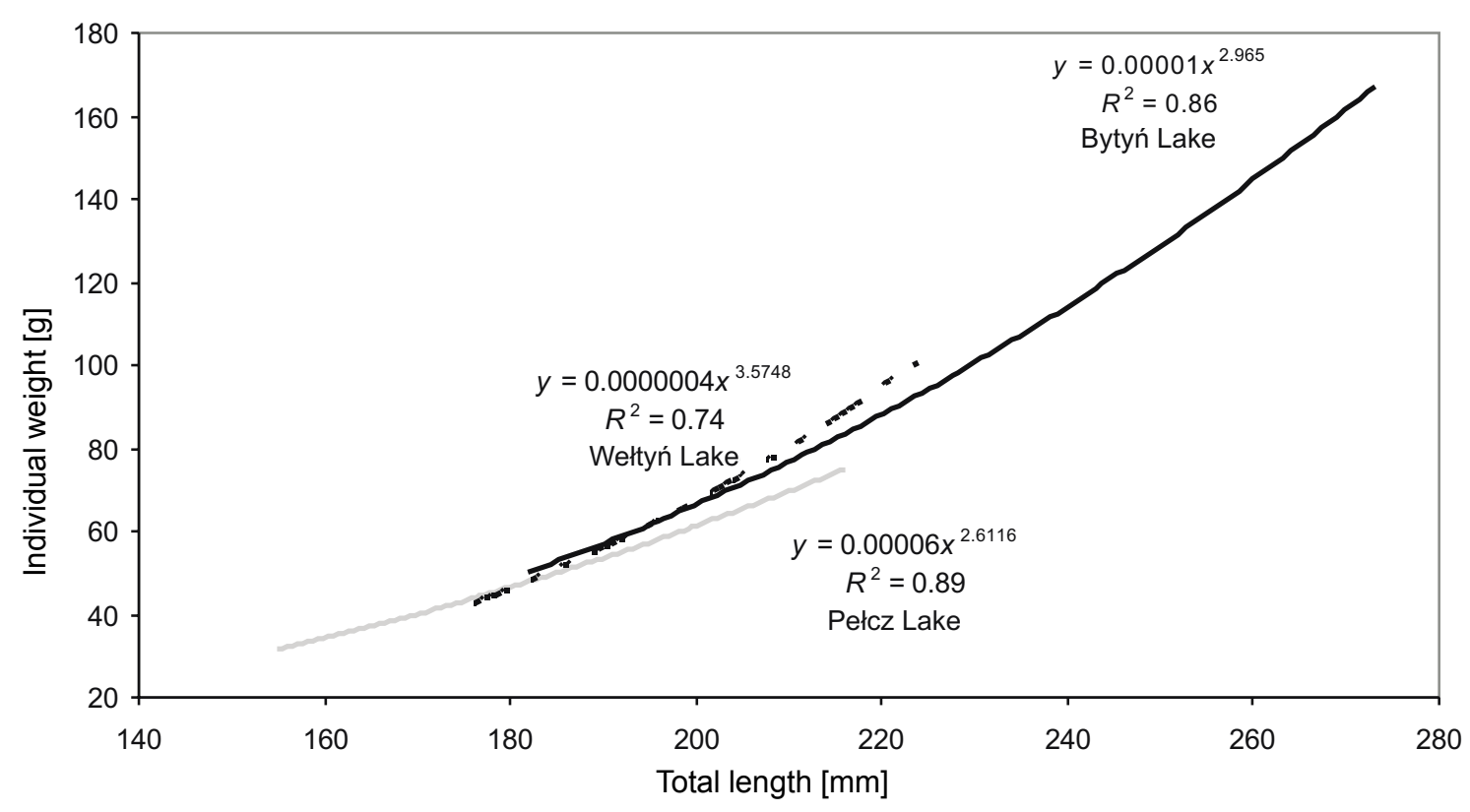

Fig. 1. Relation between the total length and weight of vendace from individual lakes

ved the fastest rate of length growth in their first year of than fish from the remaining lakes. However, the growth life (mean values of 111.8-127.5 mm). Growth rates in rate of these fish declined in next years, probably due to an the 2nd and 3rd years were 2-3 times slower compared to insufficient supply of plankton, which are the feeding base the values from the previous year. for vendace. Because of this, the highest values for length

At the end of their 1st year, fish from Pełcz Wielki La- in the following years and the largest asymptotic length ke were more than 10 percentage points larger in length were achieved by fish from Wełtyń Lake (Table 3 ).

Table 3

Growth rate of vendance from individual lakes as determined by back-calculation and von Bertalanffy's mathematical model

\begin{tabular}{|c|c|c|c|}
\hline Method & $\begin{array}{c}\text { Pełcz Wielki } \\
\text { Lake }\end{array}$ & $\begin{array}{c}\text { Bytyń Wielki } \\
\text { Lake }\end{array}$ & Wełtyń Lake \\
\hline \multicolumn{4}{|c|}{ Length growth [mm] } \\
\hline \multicolumn{4}{|c|}{ Back-calculation } \\
\hline$l_{1}$ & 127.5 & 113.5 & 111.8 \\
\hline$l_{2}$ & 169.2 & 164.4 & 169.4 \\
\hline$l_{3}$ & 189.7 & 194.8 & 209.4 \\
\hline$l_{4}$ & 193.0 & - & - \\
\hline \multicolumn{4}{|c|}{ von Bertalanffy's } \\
\hline$l_{1}$ & 136.2 & 110.7 & 109.1 \\
\hline$l_{2}$ & 166.3 & 167.1 & 172.6 \\
\hline$l_{3}$ & 184.7 & 194.2 & 208.5 \\
\hline$l_{4}$ & 195.8 & - & - \\
\hline$l_{\infty}$ & 213.2 & 219.2 & 255.1 \\
\hline \multicolumn{4}{|c|}{ Weight growth $[\mathrm{g}]^{*}$} \\
\hline$W_{1}$ & 18.93 & 12.39 & 8.41 \\
\hline$W_{2}$ & 39.61 & 37.17 & 37.15 \\
\hline$W_{3}$ & 53.40 & 61.46 & 79.27 \\
\hline$W_{4}$ & 55.86 & - & - \\
\hline
\end{tabular}

*determined from the length values (back-calculations) converted to the weight ( $\left.W=K \cdot L^{n}\right]$ 
The lengths determined by back-calculation with the Rosa-Lee procedure were used to determine the parameters for a mathematical length growth model, according to von Bertalanffy's equation. These models are as follows:

Pełcz Wielki Lake: $L_{\mathrm{t}}=213.22\left[1-e^{-0.49576(1+}\right.$ 1.055013)]

Bytyń Wielki Lake: $L_{\mathrm{t}}=219.17\left[1-e^{-0.733553(1+}\right.$ 0.040147)]

Wełtyń Lake: $L_{\mathrm{t}}=255.08\left[1-e^{-0.571108(1+0.023036)}\right]$ Where $L_{\mathrm{t}}$ is total length [mm] of fish at age of $t$ years

It should be emphasized that the average absolute difference in length obtained from empirical (from back-calculations) and theoretical results (from von Bertalanffy's model) was only $2.03 \mathrm{~mm}$ for fish from Bytyń Wielki Lake, $2.27 \mathrm{~mm}$ for Wełtyń Lake fish, and $4.85 \mathrm{~mm}$ for vendace of Pełcz Wielki Lake. These small differences support the validity of the mathematical model based on the empirical data (Table 3 ).

Table 3 also shows the results of the analysis of weight growth for the three populations. In the first year of fish life, significant differences were observed in individual weights (from $8.41 \mathrm{~g}$ for Wełtyń Lake fish to $18.92 \mathrm{~g}$ for Pełcz Wielki Lake fish). In the second year of life these differences largely decreased, ranging from 37.15 to 39.61 $\mathrm{g})$, but in the third year fish from Pełcz Wielki Lake were definitely the smallest (53.40 g).

\section{DISCUSSION}

In the second half of the 20th century Polish inland fishermen were mainly dependent on the number of eels obtained. Nowadays, due to high stocking rates, vendace has become the most valuable species, especially in lakes with comparatively low trophic level and suitable hydrochemical parameters. The preferred targets are 2- and 3year old fish, because of their size (Bernatowicz et al 1975). Gillnets of $24 \mathrm{~mm}$ mesh size are the principal gear of choice, because of their comparative selectivity. This mesh size allows the capture the fish from 17.8 to $24.2 \mathrm{~cm}$ long, with fish of $21.0 \mathrm{~cm}$ caught most effectively (Ciepielewski 1974). Consequently, the fish in Lakes Pełcz Wielki, Bytyń Wielki and Wełtyń have no chance to reach their maximum age and size of 9 years and $32 \mathrm{~cm}$ (Bauch 1966), respectively.

The most useful tools used for evaluation of fish populations, are the mathematical equations or parameters intended to estimate fish condition, using the relation between total length and weight (Le Cren 1951, Bolgier and Connolly 1989, Ritterbusch-Nauwerck 1995). The condition of vendace from the three lakes studied was evaluated using the Fulton's condition factor. The values obtained fitted the range of values most commonly reported for vendace (Szypuła 1970, Winfield et al. 1996, Czerniejewski et al. 2002). Slight differences in the mean values between the results obtained and the published data could be the result of different year seasons at capture and the fact that the influence of fish length on the Fulton' condition factor value was not taken into consideration in the analyses. Another well-being index of the fish is the relation between length and weight of fish, which is usually an exponential function. The exponent value of this function approximates 3 for vendace (Sandlund 1992, Christianus 1995), which translates into the isometric character of vendace growth. In some lakes, rich in crustacean zooplankton, this parameter is almost 3.5 (Winfield et al. 1996), but in lakes characterized by unfavourable environmental condition for vendace, the value of the exponent is less than 2.5 (Czerniejewski et al. 2002). Among vendace from lakes Pełcz Wielki, Bytyń Wielki, and Wełtyń, the lowest value of " $n$ " parameter of the relation between total length and weight was represented by fish from Pełcz Wielki Lake. It is therefore evident that the latter body of water provides inadequate quantities of food organisms (of possible inadequate quality) for this fish species, resulting probably from water eutrophication (Bnińska and Wołos 1998, Heese and Pociecha 2000). It is also possible that additional major reason contributing to the observed low values of this parameter and the condition factor of vendace were parasites, mainly tapeworms, Diphyllobothrium latum, infecting the fish (Irena Kramer, personal communication).

According to Bauch (1966), the above-mentioned characteristics, in addition to specific environmental conditions of individual lakes, play also an important role in vendace growth. It is generally thought that lakes with low trophic level index (i.e., deficient in mineral salts and fish food) are characterized by low vendace production and growth rates, in comparison with higher-trophy bodies of water. For example, in extremely oligotrophic lakes of northern Finnland, the length of vendace at the age of five does not exceed $20 \mathrm{~cm}$ (Viljanen 1986). In Polish lakes, which are far richer in nutrients and feed for vendace and with better conditions, fish grow much better (Table 4). In addition to the abundant zooplankton in these lakes, the fish growth is strongly influenced by the size of the reservoir (Marciak 1970), its depth, transparency, oxygenation during summer stagnation (Bernatowicz et al. 1975), and the population size. Christianus (1995) claimed that the highest growth rate of vendace is generally observed in small reservoirs (28-120 ha) with a depth of $21-42.5 \mathrm{~m}$ and with high water transparency. Because of high diversity of Polish lakes, growth rates of individual vandace populations are also diversified. It is evident (Table 4) that, the highest growth rates were recorded for the populations representing the Great Poland Lakeland and Pomerania (Mastyński 1978, Marszałek 1961, Marciak 1970, presently reported data), compared to those of Masuria (Christianus 1995). Higher growth rates obviously indicate better live conditions. In order to evaluate accurately the growth rate of fish examined, taken from lakes Pełcz Wielki, Bytyń Wielki, and Wełtyń, the presently acquired data were confromted with individual growth classes defined by Szczerbowski (1978) (Fig. 2). Among the three populations of vendace analyzed, the fish from Wełtyń Lake were characterized by an average growth rate, whilst the populations from lakes Bytyń Wielki and Pełcz Wielki were characterized by slow growth. It is interesting that the initial rapid growth of vendace from 
Table 4

The length growth rate of vendace $[\mathrm{cm}]$ from selected Polish Lakes

\begin{tabular}{|c|c|c|c|c|c|c|c|}
\hline \multirow{2}{*}{ Lake } & \multicolumn{6}{|c|}{ Total length in sequential years of life $[\mathrm{cm}]$} & \multirow{2}{*}{ Author } \\
\hline & 1 & 2 & 3 & 4 & 5 & 6 & \\
\hline Maróz & 9.50 & 13.70 & 15.80 & 19.20 & - & - & \multirow{4}{*}{$\begin{array}{c}\text { Christianus } \\
1995\end{array}$} \\
\hline Lutry & 10.70 & 14.60 & 15.60 & - & - & - & \\
\hline Narie & 9.50 & 14.50 & 16.60 & 17.10 & - & - & \\
\hline Isąg & 11.40 & 16.70 & 19.10 & 21.40 & - & - & \\
\hline Gorzyń & 11.20 & 17.90 & 23.20 & - & - & 一 & Mastyński 1978 \\
\hline Wdzydze & 8.00 & 14.50 & 19.60 & 23.10 & 26.10 & 28.40 & Marszałek 1961 \\
\hline Płęsno & 13.20 & 19.70 & 23.00 & - & - & - & \multirow{5}{*}{ Marciak 1970} \\
\hline Cieszęcin & 9.90 & 18.10 & 22.90 & 25.90 & 27.40 & - & \\
\hline Łętowo & 15.80 & 20.50 & 22.50 & - & - & - & \\
\hline Żerdno & 14.90 & 21.30 & 24.70 & 26.70 & - & - & \\
\hline Ińsko & 13.70 & 20.50 & 23.50 & 26.30 & - & - & \\
\hline Pełcz Wielki & 12.75 & 16.92 & 18.97 & 19.30 & - & - & \multirow{3}{*}{$\begin{array}{l}\text { Presently } \\
\text { reported data }\end{array}$} \\
\hline Bytyń Wielki & 11.35 & 16.44 & 19.48 & - & - & - & \\
\hline Wełtyń & 11.18 & 16.94 & 20.94 & - & - & - & \\
\hline
\end{tabular}

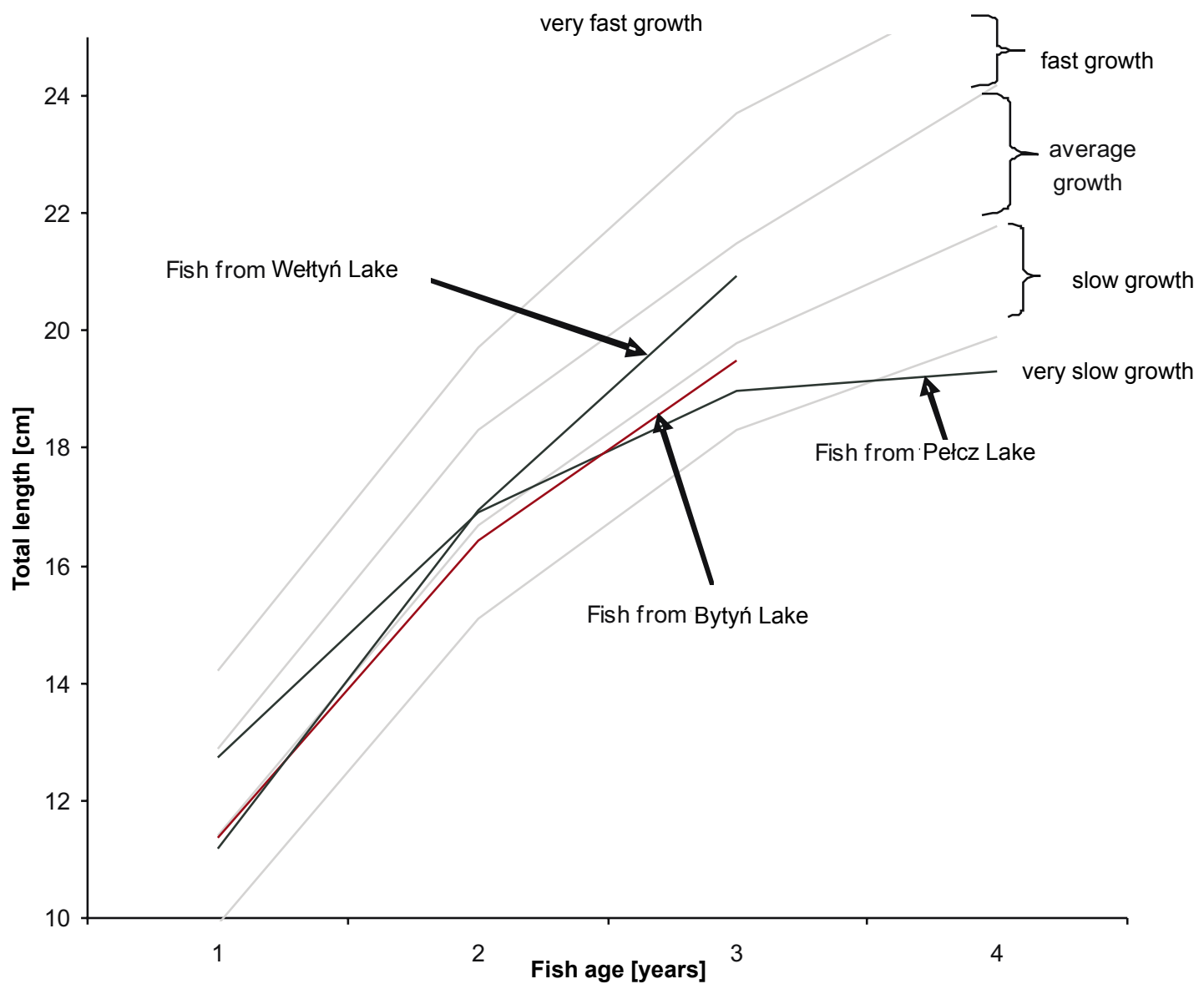

Fig. 2. The estimation of growth rate of vendace examined (according to the scale of Szczerbowski 1978) 
Pełcz Wielki Lake declined in older fish. This may be due to unfavourable hydrochemical conditions during intensive growth period in the lake, along with the parasite infection (mainly Diphyllobothrium latum). As shown in the work of Waldemar Piasecki (unpublished) in Pełcz Wielki Lake, the lack of oxygen restricts vendace movement and feeding to the upper 7-m layer of water, limiting the feeding area of the fish and contributing to easier transmission of certain pathogens.

\section{RECAPITULATION}

- The growth of vendace from the three lakes was typical for the species, i.e., very fast growth in the first year of life and significant (almost 2-3-fold) decrease in the following years.

- The growth-rate analysis determined through back-calculation showed differences between the populations of vendace from lakes Pełcz Wielki, Bytyń Wielki, and Wełtyń in sequential years of fish life. The fish from Wełtyń Lake were characterized by an average growth rate, whilst the fish from the two other lakes grew slowly or very slowly.

- The lengths calculated by back-calculation, using the Rosa-Lee procedure, were used to determine a mathematical length growth model according to the von Bertalanffy's equation. These models are shown as follows:

- Pełcz Wielki Lake: $L_{\mathrm{t}}=213.22\left[1-e^{-0.49576(1+}\right.$ 1.055013)]

- Bytyń Wielki Lake: $L_{\mathrm{t}}=219.17\left[1-e^{-0.733553(1+}\right.$ 0.040147)]

- Wełtyń Lake: $L_{\mathrm{t}}=255.08\left[1-e^{-0.571108(1+0.023036)}\right]$

- Mean values of Fulton's condition factor were 0.75 (range 0.66-0.90) for Pełcz Wielki Lake, 0.79 (range 0.65 to 1.01 ) for Bytyń Wielki Lake, and 0.75 (range 0.59 to 1.09 ) for Wełtyń Lake. Estimated condition indexes for particular lake are close to those presented in the literature for other vendace reservoirs.

\section{REFERENCES}

Bauch G. 1966. Die einheimischen Süßwasserfische. 5. Auflage. Neumann Verlag, Radebeul.

Begenal T. (ed.) 1978. Methods for assessment of fish production in fresh waters. Third edition. Blackwell Scientific Publication, Oxford.

Bernatowicz S. 1952. Zagadnienie trafności oznaczania wieku i przyrostu sielawy na podstawie łusek z różnych okolic. [On the problems of correct age- and growth increment determination of vendace from scales collected from various parts of the body.] Roczniki Nauk Rolniczych B 65: 311-335. [In Polish.]

Bernatowicz S., Dembiński W., Radziej J. 1975. Sielawa. [The vendace.] PWRiL. Warszawa. [In Polish.]

Bnińska M., Wołos A. 1998. Effectiveness of coregonid management versus environment quality. Archives of Polish Fisheries 6: 295-314.

Bolgier T., Connolly P.L. 1989. The selection of suitable indices for the measurement and analysis of fish condition. Journal of Fish Biology 34: 171-182.
Christianus J. 1995. Age and growth of selected vendace (Coregonus albula L.) populations in Poland. Archiv für Hydrobiologie, Special Issues in Advanced Limnology 46: 97 102.

Ciepielewski W. 1974. Względne liczebności roczników sielawy w jeziorze Maróz. [Relative abundance of vendace year-classes in Lake Maróz.] Roczniki Nauk Rolniczych $\mathbf{H}$ 96: 31-47. [In Polish.]

Le Cren E.D. 1951. The length-weight relationship and seasonal cycle in gonad weight and condition in the perch (Perca fluviatilis). Journal of Animal Ecology 20: 201-219.

Czerniejewski P., Filipiak J. 2001. Występowanie sielawy (Coregonus albula L.) w jeziorach Pomorza Zachodniego. [The occurrence of vendace (Coregonus albula L.) in Western Pomeranian Lakes.] Komunikaty Rybackie 52001 (64): 3-7. [In Polish.]

Czerniejewski P., Filipiak J., Przybył A. 2002. Biological characteristics of vendace (Coregonus albula L.) from the Tuczno Wielkie and Siecino lakes. Scientific Papers of Agricultural University of Poznań, Animal Science 4: 77-90

Filipiak J., Raczyński M. 2000. Jeziora zachodniopomorskie (zarys faktografii). [Lakes of Polish Western Pomerania; fact sheets.] Wydawnictwo Akademii Rolniczej w Szczecinie. [In Polish.]

Grudniewski C. 1970. Zakładanie się łusek u sielawy (Coregonus albula L.). [Establishment of scales in vendace ( $\mathrm{Co}$ regonus albula L.).] Roczniki Nauk Rolniczych H 92: 1725. [In Polish.]

Heese T., Pociecha A. 2000. Możliwości i ograniczenia gospodarki sielaowowej w jeziorach Siecino i Wilczkowo (Pojezierze Drawskie). [Potential- and limitations of the vendace management in Siecino and Wilczkowo lakes (Drawskie Lakeland).] Pp. 129-141. In: Rybactwo jeziorowe; V Krajowa Konferencja Rybackich Użytkowników Jezior; 14-16 czerwca 2000, Olsztyn, Poland. Wydawnictwo Instytutu Rybactwa Śródlądowego, Olsztyn. [In Polish.]

Jańczak J. (ed.) 1996. Atlas jezior Polski. Atlas Pojezierza Wielkopolskiego i Pomorskiego w granicach dorzecza Odry. [Atlas of Polish lakes. Atlas of the Lake Districts of Great Poland and Pomerania within the Odra River drainage basins.] Bogucki Wydawnictwo Naukowe, Poznań. [In Polish.]

Leopold M., Wołos A. 1999. Analiza stanu jeziorowej produkcji rybackiej w 1998 roku. [Analysis of lacustrine fish production in 1998.] Pp. 7-16. In: Rybactwo jeziorowe; IV Krajowa Konferencja Rybackich Użytkowników Jezior; 9-11 czerwca 1999, Dadaj, Poland. Wydawnictwo Instytutu Rybactwa Śródlądowego, Olsztyn. [In Polish.]

Marciak Z. 1970. Zagospodarowanie jezior sielawa. [Vendace management in lakes.] Wydawnictwo Instytutu Rybactwa Śródlądowego, Olsztyn No. 39. [In Polish.]

Marszałek W. 1961. Wzrost sielawy w jeziorze Wdzydze. [Growth rate of vendace in Wdzydze Lake.] Roczniki Nauk Rolniczych 93 D: 201-220. [In Polish.]

Mastyński J. 1978. Sieja (Coregonus lavaretus L.) i sielawa (Coregonus albula L.) w jeziorach Polski Zachodniej. [Whitefish (Coregonus lavaretus L.) and vendace (Coregonus albula L.) in lakes of west Poland.] Roczniki Akademii Rolniczej w Poznaniu. Rozprawy Naukowe 85: 1-26. [In Polish.] 
Nash R.D.M., Valencia A.H., Geffen A.J. 2006. The origin of Szypuła J. 1970. Wzrost i rozmieszczenie narybku sielawy w Fulton's condition factor-setting the record straight. Fisheries 31: 236-238.

Ricker W.E. 1975. Computation and interpretation of biological statistics of fish populations. Bulletin of the Fisheries Research Board of Canada 191: 1-382.

Ritterbusch-Nauwerck B. 1995. Condition or corpulence, fitness or fatness: a discussion of terms. Archiv für Hydrobiologie, Special Issues in Advanced Limnology 46: 109-112.

Sandlund O.T. 1992. Differences in the ecology of two vendace population separated in 1895 . Nordic Journal of Freshwater Research 67: 52-60.

Szczerbowski J.A. 1978. Ocena tempa wzrostu sielawy, siei, leszcza, płoci i sandacza jako podstawy określania wymiaru gospodarczego. [An assessment of the growth rates of vendace, common whitefish, carp bream, roach, and zander as a benchmark for determining the marketable size.] Broszury Rybackie No. 114. [In Polish.]

Received: 3 January 2006

Accepted: 12 June 2006 of Coregonus albula L. in Legińskie and Wydryńskie Lakes.] Roczniki Nauk Rolniczych H 92(3): 45-60. [In Polish.]

Viljanen M. 1986. Biology, propagation, exploitation and management of vendace (Coregonus albula L.) in Finland. Archiv für Hydrobiologie, Beihefte: Ergebnisse der Limnologie 22: 73-97.

Winfield I.J., Cragg-Hine D., Fletcher J.M., Cubby P.R. 1996. The conservation ecology of Coregonus albula and $C$. lavaretus in England and Wales, U.K. Pp. 213-223. In: Kirchchhofer A., Hefti D. (eds.) Conservation of endangered freshwater fish in Europe. Birhauser Verlag, Basel. 